\title{
Normalized Exceptions and Totalized Potentials: Violence, Sovereignty and War in the Thought of Thomas Hobbes and Giorgio Agamben
}

\author{
Anna-Verena Nosthoff \\ M.A. in Sociology, Postgraduate Student, Department of Social Sciences, \\ Johann Wolfgang Goethe-Universität Frankfurt am Main \\ Address: Theodor-W.-Adorno-Platz 1, 60323 Frankfurt am Main, Germany \\ E-mail: anna.verena.nosthoff@googlemail.com
}

This study seeks to critically explore the link between sovereignty, violence and war in Giorgio Agamben's Homo Sacer series and Thomas Hobbes's Leviathan. From a brief rereading of Leviathan's main arguments that explicitly revolves around the Aristotelian distinction between actuality/ potentiality, it will conclude that Hobbesian pre-contractual violence is primarily based on what Hobbes terms "anticipatory reason" and the problem of future contingency. Relying on Foucauldian insights, it will be emphasized that the assumption of certain potentialities suffices in leading to Hobbes's well-known conclusion that the state of nature is a "condition of Warre." In a second step, this study considers some of Agamben's arguments to account for how pre-contractual violence as envisioned by Hobbes cannot be rendered impotent through the integration of a sovereign. In specific, Agamben's claims shed light on an irreducible, inextricable entwining between the state of nature and the state of law as "Siamese twins" (Virno). On a meta-level, Agamben thus implicitly shows how the "Hobbesian problem" cannot be merely reduced to a "problem of order" (Parsons). With regard to the current functioning of the stratagems of financial markets and the mechanisms of future-colonization underpinning global politics, this study finally argues that Hobbes ought to be reevaluated in particular regarding the problem of the future in his account. Partly responding to Agamben's critical investigations, I suggest that a careful exploration of what will be coined "the prospects of an actualization of the potentiality not-to-be" might serve as a first theoretical step towards a productive form of criticism.

Keywords: Giorgio Agamben, Michel Foucault, Thomas Hobbes, violence, state of war, state of exception, thanatopolitics, neoliberal governance

"We are at war with one another; a battle front runs through the whole of society, continuously and permanently..."

-Michel Foucault

"Hobbes ... was speaking not to men in a state of nature, but to men in an imperfect political society, that is to say, in a society which did not guarantee security of life and commodious living..."

-C. B. MacPherson

(c) Anna-Verena Nosthoff, 2015

(C) Russian Sociological Review, 2015

DOI: $10.17323 / 1728-192 \mathrm{X}-2015-4-44-76$ 


\section{Actual(ized) Potential: Conditions of War}

In his Multitude: Between Innovation and Negation, the Italian philosopher and semiologist Paolo Virno (2008: 26) recently raised the following significant and timely question: "What is ... the effective relationship between the state of nature and the civil state? Is it that between the one and the other there is a true caesura? Or are we facing Siamese twins obliged to take turns to support one another?"

This study considers Virno's question as its major focus, and attempts to provide an account of the relation between post- and pre-contractual states through a discussion of the works of Giorgio Agamben, and by briefly revisiting Thomas Hobbes's argumentative account of the emergence of the state of nature, particularly on Foucauldian grounds. From a brief rereading of Leviathan's main arguments that explicitly revolves around the Aristotelian distinction between actuality and potentiality, ${ }^{1}$ the study concludes that Hobbes's illustration of pre-contractual violence is significantly based on "anticipatory reason." ${ }^{2}$ Relying on Foucauldian insights, the cause for "fear of violent death" (Strauss) in Hobbes could be argued to not be actuality but potentiality.

In contrast to pre-contractual violence, post-contractual violence (in Hobbes's sense) was to function as the sovereign's tool to assure overall negative liberty, first occurring within calculable means-end relations. However, alongside Agamben's claims, this study argues that Hobbes's notion of post-contractual violence merely functions as a superficial enclosure of pre-contractual violence. Rather than transforming the character of pre-contractual violence, it occurs in a different form, that is, it materializes differently within the threshold of potentia and actualitas via centralizing in the Sovereign's body. The upshot of the claim that pre- and post-contractual violence do not change per se but only by way of their respective materialization-or, "artificial" embodiment, as it wereis that pre- and post-contractual topoi as depicted by Hobbes are, in a sense, rather indistinguishable, or, to argue with Agamben, that the state of nature is still predominant as potentiality within the state.

Virno's question as raised above brings us close to the core of Agamben's central arguments as articulated in texts of his Homo Sacer series, in particular his widely discussed Homo Sacer: Sovereign Power and Bare Life (Homo Sacer I, 1); State of Exception (Homo Sacer II, 1), as well as Stasis: Civil War as a Political Paradigm (Homo Sacer II, 2, based on two Princeton lectures originally held in 2001). What Agamben indicates therein throughout is that pre-contractual violence as envisioned by Hobbes cannot be rendered entirely impotent through the integration of an absolute sovereign. In this sense, Agamben's arguments shed light on the irreducible, inextricable entwining between the State

1. Surely, Hobbes's entire Leviathan was intended to criticize Aristotle's conflation of ethics and politics. However, I am convinced that rereading Hobbes on the grounds of Aristotle's ontological categories will prove fruitful in understanding the dynamics that underpins Leviathan in spite of his critique of Aristotle.

2. In this instance, I seem to be departing from William Rasch (2007: 102) who speaks of a Hobbesian assumption of a natural or an anthropological evil. Here, I will assert, to the contrary, that the assumption of sole potentialities suffices to account for the occurrence of the Hobbesian "condition of Warre." 
of Nature (hereafter SoN) and the State of Law. ${ }^{3}$ His claims point to how pre-contractual violence survives the contractual agreement, thereby rendering the boundary between pre- and post-contractual states and the form of violence accompanying them undecidable. Noticeably, through his evaluation of contemporary realpolitik, Agamben accounts for various forms of actualized violence that unmask themselves within a topographical matrix underpinned by bio-thanatopolitical power (politics going beyond biopolitics in not only producing life but also in "making die" for the sake of "making live" within zones of indistinction). On a meta-level, Agamben thus implicitly shows how the "Hobbesian problem" cannot be merely reduced to a "problem of order" (Parsons)4, but that the SoN and the SoL can in fact be considered as "Siamese twins," as was implicitly suggested by Virno.

With regard to the current functioning not just of global realpolitik but also of the stratagems of financial markets and the mechanisms of future-colonization underpinning global politics, this study concludingly argues for a careful reconsideration of Agamben's recent theoretical interventions. In partial agreement with Agamben's claims, I consider this re-examination necessary in view of the realpolitik predominance of an undecidable threshold between the SoN and SoL in times of seemingly infinitely postponed crises. I contend that Hobbes ought to be reevaluated in particular regarding the current, temporal extension of violence into the future(s), which is (are) successively colonized by financial capital, and with regard to the uncannily dominant specter of algorithmic modes of probability, currently installed to construct predictability for the sake of solving future contingencies. ${ }^{5}$ Respectively, this study argues that a contemporary rereading of Hobbes should distinctly focus on the problem of the future in his account. ${ }^{6}$

Partly responding to Agamben's critical investigations, this study finally suggests that a careful exploration of what will be coined "the prospects of an actualization of the potentiality not-to-be" might serve as a first theoretical step towards a productive form of criticism.

\section{Rereading Hobbes: Sufficient Potential, Anticipatory Reason, and Future- Colonization}

While this is not the place to reexamine the whole of Hobbes's line of reasoning provided in his Leviathan, I at least consider it essential to reframe the core assumption of its arguably most famous chapter (Chapter 13). Its grounding thesis can be narrowed down to the following assertion: "[D]uring the time men live without a common Power to keep them

3. Hereafter SoL. I intentionally refrain from using "Civil State" here to implicitly point to the critiques of Agamben, Derrida, and Benjamin of the irreducible violence inherent in the origin of the Law, and, with it, the state (what Agamben will term "Force-of-Law"). Agamben also uses the term "state of law."

4. Cf. Parsons (1937). See also Filippov's (2013) insightful critique of Parson's and Tönnies's readings of Hobbes, as well as van Krieken (2002).

5. Cf. Streeck's (2014) analyses in this respect, alongside Vogl's (2014; 2015), and Berardi's (2012) most recent interventions.

6. A rare, insightful paper in this regard has been provided by Michaelis (2007). 
all in awe, they are in a condition which is called Warre; and such a warre, as is of every man, against every man" (Hobbes 1985: 185).

Following Hobbes's line of reasoning, two premises are particularly critical in order to derive this assertion, first, the equality of the potential to kill anyone ${ }^{7}$, and second, the equality of prudence ${ }^{8}$. It is vital to take both into account regarding the question of violence (alongside Hobbes's well-known basic assumptions of a scarcity of resources and the desire for self-preservation). Regarding the equality to kill, Hobbes (1985: 183) writes: "For as to the strength of body, the weakest has strength enough to kill the strongest, either by secret machination, or by confederacy with others, that are in the same danger with himself." The second assumption (equality of prudence) centers on the notion of anticipation" ${ }^{9}$, which is of central significance for Hobbes's arguments. Most fundamentally, Hobbes claims that there is an equal common sense amongst individuals; since we cultivate anticipatory capacities, we know that anyone can potentially kill us. To quote Hobbes (1985: 185) directly: "And from this diffidence of one another, there is no way for any man to secure himself, so reasonable, as Anticipation; that is, by force or wiles, to master the persons of all men he can, so long, till he see no other power great enough to endanger him: And this is no more than his own conservation requireth, and is generally allowed."

In fact, a great deal of Hobbes's argumentative framework depends entirely on the two aforementioned assumptions, the equality to kill, and the equality of prudence. The fact that both rest on the notion of potential is important in terms of understanding Hobbes's account of violence, particularly with regard to Agamben's timely interventions, which will be the main focus of the second part of this paper.

First, note that Hobbes's SoN is not referring to a state of actual continuous fighting ${ }^{10}$, but rather to a state characterized by a high likeliness for preemptive attacks to occur. This insight underpins a whole range of remarks to be found in various works of diverse political theorists (especially coming from the continental tradition). Amongst them are Michel Foucault (whose inversion of the Clausewitzian argument is well-known), Paolo Virno in his Multitude, and Gilles Deleuze (1961) in a hitherto-unpublished lecture note. ${ }^{11}$

7. Foucault refers to this potential as a "minor difference" which causes the ongoing struggle characteristic of the Hobbesian state of nature. According to his reading of Hobbes, the integration of the sovereign establishes a major inequality. See Foucault (2004: 90-91).

8. I rely partly on Rawls' argumentative reconstruction here: see Rawls (2007: 48ff.).

9. Rawls (2007: 49) writes about Hobbesian anticipation being "the state of affairs in which the disposition to strike first when the circumstances seem propitious is generally and publicly known, and is, by definition, a state of war."

10. This also relates to questions of reciprocity, expanded upon, for instance, by Robert Axelrod (1987).

11. Deleuze offers a reading of Hobbes and Rousseau which centers around the passage à l'acte from the virtual to the actual: "Les conflits entre individus entraînent mécaniquement des conflits intérieurs à l'individu (entre l'ambition et la peur de la mort violente)." Cf. Deleuze's hitherto unpublished lecture notes (1961). Full details are given in the bibliography. Furthermore, connected with the focus on potentiality in Hobbes's SoN is often an implicit assertion that there is no distinct line between pre- and post-contractuality, including the claim that Hobbes's SoN is, to some extent, always-already inscribed into social settings. It might not be all too surprising, then, that some explicit mentions of Hobbes have recently compared the SoN to frameworks underpinning neoliberal societies, including their institutional modes of governance. To name but a few ex- 
In the following, I will turn to some of these authors to explicate what I conceive of as the nature of "potential" violence in Hobbes's SoN, which, as will be suggested, might not at all be absent from contemporary modes of governance.

First, as I have already indicated, it is curious that Hobbes never explicitly mentions any becoming-actual of violence in the SoN. It is not without importance to highlight how he subsequently speaks of a "condition of Warre" and not of "Warre" as such" ${ }^{12}$; and how he points to scenarios where people point weapons at each other rather than to actual shootings obeying specified tactics or strategies. Foucault (2004: 92) is thus right when, in Il faut défendre la société, he claims that Hobbes's picture of the SoN tells us nothing about the kind of warfare characterizing it (if there is any):

[T] he state Hobbes is describing is not at all a brutish state of nature in which forces clash directly with one another. In Hobbes's state of primitive war, the encounter, the confrontation, the clash, is not one between weapons or fists, or between savage forces that have been unleashed. There are no battles in Hobbes's primitive war, there is no blood and there are no corpses. There are presentations, manifestations, signs, emphatic expressions, wiles, and deceitful expressions, there are traps, intentions disguised as their opposite, and worries disguised as certainties. We are in a theater where presentations are exchanged, in a relationship of fear in which there are no time limits; we are not really involved in a war.

So all in all, for Foucault (2004: 92), Hobbes's SoN is rather a "sort of unending diplomacy" as he terms it, wherein what is significant in the first place is "my presentation of the strength of the other's presentation of my strength and so on." Hobbes's SoN, then, is first and foremost a "state of fear," implicating a not-yet-actual violence in which "the will to contend by battle is publicly recognized" (Rawls, 2007: 53). Hobbes's (1985: 186) own, most distinct remarks pointing in this direction are crystal clear: "The nature of War consisteth not in actuall fighting; but in the known disposition thereto, during all the time there is no assurance to the contrary."

Borrowing from Agamben's (Aristotelian) definition of potentiality, ${ }^{13}$ the anticipated, potential violence described by Hobbes thus does not necessarily "disappear immediately into actuality" (Agamben, 1998: 45). It is rather a projected probability underlying some future contingent. What Hobbes seems to have in mind is a somewhat immaterial and

amples, Critchley (2014) draws the analogy, even if somewhat loosely, in the context of the university. More explicit are Jeremy Gilbert's recent Common Grounds (2014), and still most relevant, C. B. MacPherson's influential The Theory of Possessive Individualism (1962).

12. Moreover, Hobbes (1985: 186) explicitly claims: "For WARRE consisteth not in Battell only, or the act of fighting, but in a tract of time, wherein the Will to contend by Battell is sufficiently known: and therefore the notion of Time, is to be considered in the nature of Warre; as it is in the nature of Weather."

13. As Aristotle asserts in Metaphysics: "A thing is said potential if, when the act of which is said to be potential is realized, there will be nothing im-potential (that is, there will be nothing able not to be)" (quoted in Agamben, 1998: 45). Agamben concludes (1998: 46): "What is potential can pass over into actuality only at the point at which it sets aside its own potential not to be (its adynamia). To set im-potentiality aside is not to destroy it, but on the contrary, to fulfill it, to turn potentiality back upon itself in order to give itself to itself." A detailed explanation of this is provided in Agamben (1999b: 177-219). 
invisible form of violence, which can be felt through its potential, resting on highly psychological mechanisms. As Hampton nicely summarizes, the Hobbesian SoN can, thus, best be characterized as a high-risk situation giving rise to mutual misperceptions which "disrupt many people's reasoning ... while the rest fear this disruption and . . refuse to cooperate to avoid being exploited." ${ }^{14}$ Very illuminating in this context is a Plautinian assertion that Derrida (2011: 61) invokes in The Beast and the Sovereign I, which illustrates this point nicely: "wolf," he claims, "is man for man, and not man, when . . one does not know which he is." ${ }^{15}$

The form of pre-contractual violence depicted by Hobbes is thus both potential and structural in that its actualization depends on the outcome of interrelational dilemmas of perception: the SoN presents a topographical and topo-logical matrix grounded in various prisoner's dilemma-like situations, resting on informational asymmetries and a lack of security in the first place. According to Hobbes, it is also on these grounds that the insight into the reasonability of anticipatory attack arises: the latter is first and foremost a consequence of the perception of a potential yet invisible threat. I cannot know the other, who is my opponent in this case. To put it in Schmittian terms, there is no concrete possibility to decide between [konkrete Möglichkeit zur Unterscheidung] friend and enemy. ${ }^{16}$ Hobbes (1985: 187) confirms this when he points to individuals' permanent suspiciousness toward each other, a picture which he obviously adopts not from his supposed "hypothetical" construct termed "state of nature" but rather, as MacPherson (1962) has aptly pointed out, from an observation of civil society. To quote Hobbes directly (1985: 187):

[W] hen taking a journey, he [i.e., man in civil society] armes himselfe, and seeks to go well accompanied; when going to sleep, he locks his dores; when even in his house he locks his chests; and this when he knows there bee Lawes, and publike Officers, armed, to revenge all injuries shall bee done him; what opinion he has of his fellow subjects, when he rides armed; of his fellow Citizens, when he lockes his dores.... Does he not thereby accuse mankind by his actions, as I do by my words?

14. See Hampton's “Hobbes's State of War” (1985). See also Haji (1991), who points to a range of difficulties in Hampton's approach. He argues that she comes up with the paradoxical final conclusion that, depending on certain factors, cooperation within the state of nature can be both rational and irrational. In this context, see also Hampton's (1991) response. As she points out, from the claim that cooperation in the state of nature is per se impossible, it follows that establishing an absolute sovereign is impossible as well. She argues that the establishment of an external force is by nature an agreement non-cooperative agents could not make. She thus argues that Hobbes is either wrong in assuming that cooperation is impossible in the state of nature or in claiming that individuals will actually manage to overcome the state of nature by establishing a sovereign. In this regard, see also Braybrookes (1985).

15. The quote refers to Plautus (2006: xi). Interestingly, the saying homo homini lupus goes back to Titus Maccius Plautus. In De Cive, Hobbes refers to this: “To speak impartially, both sayings are very true; That Man to Man is a kind of God; and that Man to Man is an arrant Wolfe. The first is true, if we compare Citizens amongst themselves; and the second, if we compare Cities" (1983: 2). Plautus' original phrase, however, entails an important second part: "Lupus est homo homini, non homo, quom qualis sit non novit." ("One man to another is a wolf, not a man, when he doesn't know what sort he is.")

16. Schmitt expands on the friend-enemy distinction in the most detailed manner in The Concept of the Political (1927). 
This quote should suffice to lend credence to MacPherson's argument. While Hobbes explicitly believes there never generally was such a thing as a "condition of warre as this" (187; with the significant exception of American Indian rural societies that Pierre Clastres (2010: 237ff.) has evaluated extensively, especially in relation to the nature of war and violence), his depiction of the state of nature is probably not as hypothetical as he depicts it to be; it is rather closer to actual societies than to any alleged "natural" condition ${ }^{17}$. In fact, upon closer reading, civil society becomes discernable as the actual, tacit mirror image of Hobbes's "condition of warre," which underpins Leviathan's 13th chapter. Hobbes writes: "But there had never been any time, wherein particular men were in a condition of warre against another; yet in all times, Kings, and Persons of Soveraigne authority ... are in continuall jealousies ... having their weapons pointing, and their eyes fixed on one another ... and continuall Spyes upon their neighbors; which is a posture of War" (1985: 188). In other words, what Hobbes describes as a "state of nature" is obviously more of a product of civil society than a pre-social state.

\section{Hobbes's Novel Prometheus: The Problem of Future Contingency}

This observation, which is prominent both in Foucault's and MacPherson's readings, brings us to another significant factor to be discussed, namely future contingency. As I would argue regarding the relation between pre- and post-contractual states, futurecontingency concerns not merely an exclusively pre-societal problematique, but one that potentially reoccurs within the state of law, and which becomes complicated therein. One might even go so far as to assert that future-contingency, grounded in anticipation, is the fictive glue that constantly holds together the state of nature and the state of law, even if the state of law on Hobbesian grounds is installed precisely to grant a considerable level of coherence and predictability. We will return to this in more detail later.

For now, let it suffice to mention that the issue of the future in Hobbes's account is an often-underrated factor regarding the emergence of the state of war. Indeed, by and large, what drives the insecurity and the reactions of agents in the SoN is not least the openness of the future, conceived of as a problem to be solved, and which itself causes the desire to proactively construct it. The emergence of the state of war as described by Hobbes could thus, as I would argue here, also be read on the terrain of the problem of futurecontingents, and the means adopted by individuals to counter it. ${ }^{18}$ Take for instance the following passage from Hobbes's Leviathan that explicitly addresses the unknowability of the future:

The Present onely has a being in Nature, things Past have a being in the Memory onely, but things to come have no being at all; the Future being but a fiction of a mind,

17. Clastres indeed points to a close analogy between American Indians of that time and Hobbes's illustration of the state of nature. While Clastres' argument is highly interesting, I will follow MacPherson's reading here and conceive of Hobbes's SoN as closely aligned with and as just a radicalization of observations of civil societies.

18. I will follow such an argumentative line in due course. 
applying the sequels of actions Past, to the actions that are Present; with which most certainty is done by him that has most Experience; but not with certainty enough. And though it be called Prudence, when the Event answereth our Expectation; yet in its own nature, it is but Presumption. For the foresight of things to come, which is Providence, belongs onely to him by whose will they are to come. (Hobbes, 1985: 97; my emphasis)

Moreover, it is significant that Hobbes draws an implicit analogy between the situation of individuals in the state of nature and Prometheus's eternal punishment (i.e., being chained to a rock in the Caucasus). According to Hobbes, this comparison holds especially true for what he calls an "over provident" individual, that is, a "man, which looks too far before him, in the care of future time, hath his heart all day long, gnawed by feare of death, poverty, or other calamity; and has no repose, nor pause of his anxiety, but in sleep" (Hobbes, 1985: 169; cf. Michaelis, 2007). Hereby, it is Hobbes's extremely idiosyncratic account of Prometheus that is striking. Literally translated, "Prometheus" means "foresight," yet, Hobbes excludes any account of his former deed (having gifted mankind with fire). Contrary to traditional Greek narratives, his reading is only interested in the Greek Titan's condition as an allegedly miserable one in which Prometheus faces an everthe-same malignant future. Respectively, Hobbes's narrative is telling precisely as it is seemingly so over-occupied with the problem of future contingency (cf. Michaelis, 2007). Seen from this stance, Hobbes's implicit account of future-colonization highlights how individuals in the State of Nature above all end up in a condition of war due to a praxis of constantly anticipating potential futures and by acting in response to these imagined future(s) in the present. Thereby, they adopt those means that allegedly shape their future which best suit their interest of self-preservation. To colonize the future in this sense is to attempt to own both time and power over the future(s).

On the grounds of the issue of future-colonization and the nature of violence as potentiality in Hobbes's SoN, it should be evident that its most challenging aspects are clearly not anthropological assumptions predetermining a somewhat egoist selfishness (Hobbes continues to be misread in this sense). Although Hobbes describes certain passions as being natural to men, ${ }^{19}$ it is not natural "radical evilness" that causes the condition in which "lupus est homo homini," but rather a lack of assurance and the will to power over the future..$^{20}$ One thing that seems clear to Hobbes in this respect is that individuals possess a natural capacity to anticipate the future, which, according to my reading, is a significant factor for the emergence of the state of war as discussed in Leviathan's first book. It is only through anticipation that I can know that someone might potentially attack me; it is in an equal sense only through the cultivation of anticipatory reason that I will be able to acknowledge the preferability of the Commonwealth over the state of nature.

"Anticipatory reason" in this sense is a sort of long-term, focused, calculating way of imagining a future-yet-to-come accompanied by the rational insight whereby individu-

19. For example, Hobbes refers to aversion, hate, joy, etc. See Hobbes (1985: 122).

20. Strauss makes a similar claim. Cf. Strauss, 2007, esp. Chapter 2. 
als acknowledge that "there must be some coercive power to compel men equally to the performance of their covenants, by the terror of some punishment" (1985: 202). According to Hobbes, the reason why individuals erect a "Common-Wealth" "to make good that Propriety ... in recompence of the universall Right they abandon" (Ibid.: 202) is that they recognize that they will be better off if they opt for security at the expense of liberty, and not least to solve the problem of future contingency driven by the desire for self-preservation, or more accurately, "the foresight of their own preservation" (Ibid.: 223).

\section{Agamben's Intervention: Introducing States of Actual War}

What will be of most interest in relation to Agamben's interventions-which will be our focus from now on-is the passage from the SoN on the collective right transferal whereby the absolute sovereign is instituted. Respectively, Foucault (2004: 88-99) rightly claims that violence here becomes centralized within the body of the sovereign before any actual, preemptive attacks occur, as has already been hinted at. In fact, there is a sense in which the evolving process of the becoming-actual of a universal, total state of war is interrupted by the establishment of the Leviathan, the condition wherein homo homini lupus est is supposedly being exchanged for the conditional principle protego ergo obligo. ${ }^{21}$ It is on these grounds that, as Agamben will implicitly show, the whole structure of Leviathan, specifically the distinction between pre- and post-contractual situations, needs to be questioned - precisely as it always-already rests on a fundamental paradox that necessarily renders the limit between SoN and SoL undecidable. In this sense, by deconstructing the logic underpinning Hobbesian contractual sovereignty, I take Agamben to consequently show that the state of actual war (in the sense of an actualization of a potential) is yet to come, precisely because, relying on Aristotelian categories, potentiality similarly requires im-potentiality to not be rendered actual, i.e., the potential's potentiality-not-to-be. ${ }^{22}$ Following Agamben, sovereignty's absolute superiority lies precisely in its potentiality-not-to-be while maintaining the potentiality-to-be, meaning that it does not limit the potential but rather maintains it, potentially rendering it actual ${ }^{23}$.

More precisely, what Agamben will show is that the actualization of potential violence that ought to be rendered im-potential by means of establishing sovereignty can be shown to (i) prevail in the figure of the sovereign, and (ii) be implemented on the grounds of a structural conflation of norm and exception that Hobbes had clearly not foreseen. However, what arises from the fact that the potential violence of the SoN can-

21. This principle goes back to Schmitt. As he (2007: 52) claims, "The protego ergo obligo is the cogito ergo sum of the state."

22. Following Heller-Roazen's (1999: 16) reading of Agamben's exploration of Aristotle's distinction between potentiality and actuality, "it is precisely the relation to an incapacity, which constitutes the essence of all potentiality."

23. I read Agamben to rely on Aristotle's definition of potentiality here. It is helpful to quote Agamben at length in relation to what he terms the Aristotelian definition of "the key figure of potentiality, the mode of its existence as potentiality": "It is a potentiality that is not simply the potential to do this or that thing but potential to not-do, potential not to pass into actuality" (Agamben, 1999: 179f.; emphasis added). 
not be rendered entirely impotential by means of establishing sovereignty (that is, as an actualized impotentiality) is an ontic-ontological (or, an-archic, as it were) threshold, which renders actuality and potentiality indistinguishable. According to Agamben, it is within this threshold that a contractually covered, actualized form of violence will occur.

\section{Agamben: Deconstructing Contractually Established Sovereignty}

As has already been indicated, for Hobbes, the "Common-Wealth" symbolizes the overcoming of a sphere of constant fear and insecurity through the integration of an external figure, the "Mortall God," which is by necessity situated beyond the law. This one person unifying the "Multitude" is authorized by the many "to keep them in awe, and to direct their actions to the common benefit" (Hobbes, 1985: 227). What Hobbes implicitly draws on is a binary opposition between those structural systems underpinning the SoN (often modeled as a Prisoner's Dilemma ${ }^{24}$ in classical game-theoretical terms) and the established State of Law (often modeled as an Assurance Game in game-theoretical terms, which is often thought of as a "solution" of the PD). Agamben, in a topographical manner, visualizes such type of relation as follows:

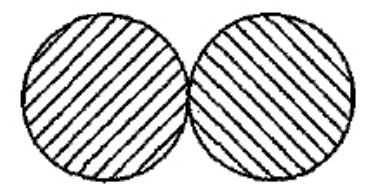

(a) (b) 25

Figure 1: Illustration of the Hobbesian assertion in an Agambenian manner. The SoN (left, [a]) and the state of law's structures (right, [b]) are logically opposed. In the case of the dissolution of the state, sovereignty is dissolving entirely, giving rise to a recurrence of the SoN in its original, atomistic, individualist form. What we confront here is, thus, an either-or of (a) or (b): $\neg \mathrm{a}=\mathrm{b} \rightarrow \mathrm{a}=\neg \mathrm{b}$. In Schmittian terms, it could be asserted that Hobbes implements the exception (the embodied SoN as conserved in unified sovereignty = Leviathan) for the sole sake of enabling permanent law-enforcement, i.e., for the creation of a securing norm (SoL). ${ }^{26}$ In the Hobbesian

24. Hereafter PD. It has, however, been subject to wide debate whether the Hobbesian State of Nature can accurately be modeled as a one-shot PD game. Although I am rather opposed to framing the Hobbesian SoN as a one-shot game and found arguments for iterated games (with brighter prospects for mutual cooperation) convincing, I will nevertheless frame the Hobbesian SoN as a one-shot PD here. It seems sufficient for a broader illustration of the Hobbesian line of reasoning. The arguments of Axelrod, Kavka, and Hampton, however, should be taken into further consideration. It is especially Kavka who challenges Hobbes's claim that anticipation is the best policy (see Kavka, 1983). For an interpretation of Hobbes's state of nature as a one-shot PD game, see, for example, Rawls (2003: 238), Barry (2010: 253-254), Gauthier (1969: 79-80).

25. Figure taken from Agamben (1998: 38).

26. On Schmitt's distinction between norm and exception, see specifically Schmitt's Dictatorship. 
Common-Wealth, the sovereign dwells in (a) and reigns over the subjects in (b), with both spheres (a) and (b), that is, the norm and the exception (allegedly) being clearly separable. ${ }^{27}$

Agamben's critique now enters the picture in shifting our perspective from the intersubjective dilemma characteristic of the Hobbesian SoN towards a predicament arising between the subject and the sovereign. I suggest that one might best grasp his critique by focusing on the terminologico-conceptual threshold arising from two slightly different notions describing the act of authorization, i.e., the Hobbesian "laying down" one's right, and the act of "transferring it." The latter reveals the origin of the relation between the sovereign and homo sacer (the emblematic figure that is bound to the sovereign while yet remaining outside the law, who (under Roman Law) could be legally killed but not sacrificed) or, the king and the multitude, which forms the core of Agamben's critique.

\section{Acts of Asymmetrical Authorization: Totalized Potentialities}

While it should be remarked that there are of course various liberal readings of Hobbes ${ }^{28}$ most notably Carl Schmitt's appallingly anti-semitic Leviathan, which draws on Hobbes as the inventor of the state as the instance of the machinic (and thus a forerunner of what Schmitt thought of as its perverted form, i.e., parliamentarism as the technical mode of governance lacking any idea of the political ${ }^{29}$ - this study intentionally focuses on parts where a risk - a potential - to totalitarianism could be decoded in the very act of transferring a right. This is specifically important to account for how Agamben will later interpret violence as always-already latent (that is, potential) within the institution of the contract. Clearly, for Hobbes, the prior aim for the establishment of the Leviathan was to preserve a considerable level of security on the grounds of coherent legal norms. Similar to Schmitt, however, Hobbes nevertheless anticipated that, for this norm to be executed, a realm exempt from it was needed. What he did in consequence then was to reserve this space for the sovereign only; it is this sphere beyond the law that Agamben will later decode as necessarily violent in an an-archical sense, i.e., it is violent before any foundation, or arché, could be established.

To be more explicit, Hobbes's Leviathan first defines the act of "authorization" ${ }^{\circ}$ as an act of appointing "one man ... that may reduce all their wills, by plurality of voices,

27. The same logic underpins Schmitt's depiction of a line of demarcation between norm and exception as articulated most significantly in his Political Theology.

28. Prominent liberal readings are, for instance, Strauss (1961), Oakeshott (1975), and, in some idiosyncratic sense, of course, Schmitt (1996b).

29. Cf. Schmitt (1996b: 61); for a critical stance on Schmitt's reading of Hobbes, see specifically Agamben (2015b: 45-48).

30. Interestingly, the Hobbesian definition of "authorization" allows for extremely contradictory interpretations. Gauthier (1969: 120-177) contends that Hobbes does not intend to make individuals subject to the sovereign, while Hampton (1986) argues against such reading on the grounds of Chapter 17 of Leviathan. As she asserts, Hobbes explicitly describes the act of rights transferal as one of "giving up one's own right." 
unto one will" (1985: 227). This consolidation of all wills can justifiably appear as a true act of unification precisely as it is being freely consented to (in an almost Rousseauean sense). In this sense, it is an expression of individual autonomy with the sovereign being an instance of concrete representation (to borrow from Schmitt). ${ }^{31}$ Here, Hobbes, again, in a remarkable resemblance to Rousseau, speaks of the "reall Unitie of them all, in one and the same person, made by covenant of every man with every man" (Ibid.). However, he continues in a slightly different fashion (and in this respect, it is not without importance to note that already in the quote cited before, he spoke of a "reduction" of wills, not of a will that adequately represents the plurality of wills). Hobbes speaks of this "one will" as becoming "his will," i.e., the sovereign's will, demanding the subjects to "submit their wills, every one of his will, and their judgments, to his judgment" (Ibid.). Again, it is entirely clear that the final possessive pronoun is reserved for the sovereign and it seems (in contradistinction to Rousseau) that the final source of legitimacy is not the demos or the unified will of the people (in the sense of a volonté générale), but is the sovereign alone. This corresponds to the absence of any institutionalised right to resistance in Hobbes within the established state of law (which arguably makes him less of a liberal than Schmitt thought). Let me quote one more striking passage taken from Chapter 28, where Hobbes writes the following about the "right to punish" (and of which Agamben [1998: 106] explicitly says that it "takes the form of survival of the state of nature at the very heart of the state," an argument that we will subsequently examine): "For the subjects did not give the sovereign that right [the right to punish.-A.N.]; but only in laying down theirs, strengthened him to use his own, as he should think fit, for the preservation of them all: so that it was not given, but left to him, and to him onely; and (expecting the limits set to him by naturall Law) as entire ..." (1985:354).

The act of exchange as it is explained here and the sovereign's specific right to punish in no way resemble any symmetrical relation (in the sense that I abdicate my right to freedom to better preserve my own security, even though preservation is still mentioned as the causa finalis of the sovereign's monopoly over the right to punish). ${ }^{32}$ On a meta-level, it is more or less impossible to not read these very ambivalent statements as a commitment to oneness as opposed to heterogeneity. This becomes distinct as well when Hobbes (1985: 227) asserts in an earlier passage that the sovereign is being appointed "to beare their [i.e., the contracting individuals' (my remark.-A.N.)] person," where a peculiar sense of intimacy characterizing the relation between the sovereign and the subject be-

31. Schmitt expands on the notion of concrete representation most concisely in Roman Catholicism and Political Form (cf., for instance, Schmitt, 1996a: 20). See also his reading of Rousseau in his Dictatorship, which is essentially concerned with the problem of representation in relation to the volonté générale and its (Jacobinian) realpolitik aftermath (cf. Schmitt, 2014: 110ff.). Particularly in response to Weimar parliamentarism, Schmitt thought that politics was in desperate need of an authority capable of embodying and intensifying "an ethos of belief [Ethos der Überzeugung]" (Schmitt 1996a: 17; my emphasis). This latter is a core belief, which is best expressed in Schmitt's reading of Rousseau in his Dictatorship, where Schmitt famously argues for complete homogeneity as a necessary precondition for concrete, coherent, and politically representative decisions.

32. Hampton points out that the "transferal" of rights resembles a "surrender" here. See Hampton (1986: 119). Foucault (2004: 94) makes a similar point: "The sovereign . . . will not simply have part of their rights, he will actually take their place, and the whole of their power." 
comes graspable alongside a radically violent potential lying at its very core which, also in some sense, underpins his account of the right to punish. There is thus a sense in which this passage could be read as tacitly anticipating a "ban" (a form of inclusionary exclusion) between the sovereign and homo sacer in Agamben's sense.

Before I explain the broader implications of the act of rights transferal on Agambenian grounds, let me briefly say a few words on Agamben's thinking on what is implied by the term "ban" (as in fact, almost all of those binaries Hobbes relies upon-i.e., peace/war, inside/outside, and even friend/enemy ${ }^{33}$ - could be read to implicitly rely on such a form of inclusionary exclusion). Agamben here refers to set theory to expand on the structural asymmetry defining the "ban" (between homo sacer and the sovereign, or between the multitude and the king), which defines membership as $b \in$ a. Hereby, membership is defined in contradistinction to inclusion, that is, the relation $b \in a$ indicates that (b) might be included in (a) without being a member of it (cf. Agamben 1998: 24). In addition, $\mathrm{b} \in \mathrm{a}$, thus, marks an asymmetrical relation that culminates in a form of "being-outside and yet-belonging” (Agamben 2005: 35). To quote Agamben at length: “. . . we shall give the name ban (from the Old Germanic term indicating both exclusion from the community and the power of the sovereign) to this original legal structure, through which law preserves itself even in its own suspension, applying to what it has excluded and abandoned, that is, banned."

Certainly, Agamben implicitly refers to Carl Schmitt's thinking on norm and exception (as most distinctly articulated in Schmitt's Political Theology), of the idiosyncratic, anarchic law of the exception that prevails if the archic, juridical law is legally abandoned (which is the state of exception), in order for it to be preserved. ${ }^{34}$ In this sense, the law is suspended, but the suspension of the law is implied in the legal order. Spoken set-theoretically, it is implied in the norm without belonging to the norm, as it installs the exception as a topos distinct from it. For Agamben, however not only the relation norm/ exception, but also the relation homo sacer/sovereign-and, as I will argue, between the people and the multitude-is determined by such set-theoretical logic implying this peculiar (non-) relation implied in the concept of a ban. ${ }^{35}$ It is significant that Agamben (1998: 107) finds this logic inherent precisely in the Hobbesian contractual agreement: "Sovereign violence is in truth founded not on pact but on the exclusive inclusion of bare life in the state." As a consequence, he argues, "the foundation of sovereign power is to be sought not in the

33. The friend/enemy distinction of course refers to Schmitt in the first place. To my mind, the Hobbesian suggestion to commonly re-locate conflicts beyond the borders of the state indeed reads like an anticipated Schmittianism here. As Hobbes (1985: 228) claims, "For by this Authoritie ... he is inabled to forme the wills of them all, to Peace at home, and mutuall ayd against their enemies abroad."

34. To quote Schmitt (2005: 6) directly from his Political Theology: "Sovereign is he who decides on the exception. ... The decision on the exception is a decision in a general sense of the word. Because a general norm, as represented by an ordinary legal prescription, can never encompass a total exception, the decision that a real exception exists cannot therefore be entirely derived from the norm. . . The exception, which is not codified in the legal order, can at best be characterized as a case of extreme peril, a danger to the existence of the state, or the like. But it cannot be circumscribed factually and made to conform to a preformed law."

35. Crucially, he departs from Schmitt (in particular, from his Dictatorship), for whom norm and exception depend on each other while still being clearly separable. 
subjects' free renunciation of their natural right but in the sovereign's preservation of his natural right to do anything to anyone" (106).

Indeed, Agamben explains this paradoxical relation with regard to Hobbes in more detail in his most recent Stasis: Civil War as a Political Paradigm, which distinctly focuses on the divergence between the concept of the people (populus) and the multitude (multitudo). According to Agamben, this distinction is not made explicit in Hobbes's Leviathan (while it, however, implicitly echoes the distinction in Chapter 18), but all the more in De Cive, in which Hobbes expands on how the people in a monarchy necessarily dissolve into a politically insignificant multitude as soon as the king is chosen. ${ }^{36}$ According to Hobbes (quoted in Agamben 2015: 33), the people "is something single ... which has one will and to whom one action can be attributed." That is, the people is equal to the king (rex est populus) (cf. Ibid.). Now, it is essential to grasp what the people de facto signify for Hobbes: "Common men, and others who do not notice these things, always speak of a great number of men, that is, of the city, as the people; they say that the city rebels against the king." Hobbes, however, counters this assertion of "common men," claiming that in a post-contractual situation, the citizens are precisely not the people but only the multitude. As Agamben (2015: 35) asserts: "The people—the body political—exists only instantaneously at the point in which it appoints 'one Man, or Assembly of men, to beare their Person' . . . but this point coincides with its vanishing into a 'dissolved multitude'. The body political is thus an impossible concept ..."

Now, what is impossible here, according to Agamben's reading of Hobbes, is the very concept of concrete representation in the sense of a strict coincidence between the multitude, the people, and the body of the king. In other words, there is no actual identity between the artificial God and the multitude except during the moment of rights-transferal. What happens thereafter, according to Agamben, is that the alleged demos, or populus, is necessarily reduced to an empty, apolitical signifier-namely, to the multitude-once the contract is established. To rely on Agamben's concepts, the establishment of the contract first follows the act of unification of a hitherto disunited multitude; secondly, within the very moment of rights-transferal, the multitude becomes the people and coincides with the king; and thirdly, in a post-contractual situation, the multitude splits again from the people and becomes dissolved (dissolved multitude). According to Agamben, it is precisely this dissolved multitude that forms the remaining trace of civil war haunting the state from the inside. To quote Agamben (2015: 40-41) directly: "If the dissolved multitudeand not the people-is the sole human presence in the city, and if the multitude is the subject of civil war, this means that civil war remains always possible within the state... Civil War and Common-wealth, Behemoth and Leviathan coexist-just as the dissolved multitude coexists with the sovereign."

While both the state (i.e., the sovereign, or the "people") as well as the state of nature (civil war, or the multitude, or as Agamben in various instances terms it, ademia, that is, the absence of the people or a demos) coexist at the same time, this, however, need not

36. Ibid. Cf. Hobbes's seventh chapter in De Cive. 
imply that they are simply identical nor strictly correlative. As I would read Agamben here, the difference between both is the level of actualization, as already indicated. The inclusively excluded multitude as the incorporation of civil war into society is-contrary to the sovereign and the people-potential. Finally, insofar as it is rendered actual, a civil war is waged within the state against the people, that is, the sovereign.

What Agamben argues thus implicitly is that the transformation of the Hobbesian contractual "transferal of rights" marks the relational origin of a ban that always-already suspends any potentiality to newly contractual arrangements on behalf of the people without a previously waged war directed against the sovereign, precisely as it is only correlative with the multitude in the very act of right-transferal. "The people," Agamben (2015b: 40; emphasis added) claims, "is the absolutely present which, as such, can never be present and thus can only be represented." Thus, Agamben witnesses the potential that in "transferring their rights," the subjects enter a relation whose very essence incorporates the potentiality - and, following Agamben's reading, the actualization-of the people's own suspension. This however does not imply that the divergence between the multitude, the people, and the king would cancel the relation between the rex and the multitude, which remains a "relation with the nonrelational," a relation between the ordering power and someone within this order who is yet not a member of it in the sense of an inclusionary exclusion (as expanded above) (Ibid.: 29). The paradoxical double bind here arises from the contractual affirmation of a potential negationary totality ${ }^{37}$; the "people" are only present in the very moment when they choose their sovereign, but, as Agamben (2013: 26) rightly claims, "this moment coincides with its vanishing in a dispersed multitude." Agamben's focus on the very act of the establishment of the relation between the sovereign and the subject, the rex and the multitude, characterized by an act of laying down that founds the potentiality of a one-sided, radical asymmetry within a topologically symmetrical structure, ${ }^{38}$ eventually confronts Hobbes's distinct, and in some sense, exclusionary focus on the problem of intersubjective violence in the state of nature with its own deficiencies.

Responding to contemporary realpolitik realities, Agamben's focus is precisely on the potential to totalitarianism that marks the relation between the sovereign and the subject (or, the king and the multitude). As outlined above, he particularly emphasizes that the Hobbesian "condition of Warre" is always-already potential even if accompanied by im-potentiality ${ }^{39}$, and that it, borrowing from Foucault's (2004: 93) sophisticated reading

37. Cf. Agamben (1998: 50-51). His concept of the ban here draws on Nancy, who expands on this in The Birth to Presence and in A Finite Thinking. As Nancy (1993: 39) claims, "to be abandoned is to be left with nothing to keep hold of and no calculation."

38. That is, both homo sacer and the sovereign are within and without the Law. As such, they have "the same structure." Moreover, as Agamben (1998: 84) claims, they are correlative: "The sovereign is the one with respect to whom all men are potentially homines sacri, and homo sacer is the one with respect to whom all men act as sovereigns."

39. Cf. Agamben 1998: 104-111. In this context, see also Foucault's (2004: 90) remark that "the state of war in the state of nature goes on even when the State has been constituted and Hobbes sees it as a threat that wells up in the State's interstices, at its limits and its frontiers." Taking a genealogical stance, he asserts that "the war of every man against every man' that characterizes the state of nature is not a real historical condition but a 
of Hobbes, remains a "permanent backdrop", and is the topographical modus operandi of the juridical, the political (and the social). Moreover, Agamben lends much credence to Schmitt's assertion that any norm always-already presupposes an exception (in the sense that Schmitt still upheld in Dictatorship). Beyond Schmitt and Hobbes, however, he grasps that the contemporary situation is far from binary and that the paradigm constitutive of the present geopolitical field is best illustrated as a merging of both. It is thus only consequential that he reconstructs the Hobbesian (and early Schmittian) binary in the following format:

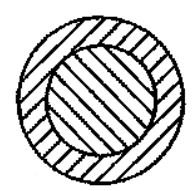

(a) $\&(b)^{40}$

Figure 2: What happens in the state of exception is the merging of both (a) and (b), i.e., the Hobbesian logic of a binary opposition between (a, exception, state of nature) and (b, norm, state of law) is rendered obsolete. The potential violence inherent in (a) is still present. The structure underpinning Hobbes's state (an Assurance Game) has not succeeded in abandoning the Prisoner's Dilemma Structure (i.e., potential violence) inherent in the SoN, logically leading to the following:

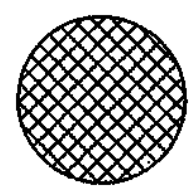

$$
\text { (a) }=(b)^{41}
$$

Figure 3: The potential inherent in (a) becomes actualized: violence becomes partly actual. The state of law is still existent insofar as sovereignty is not dissolved while the SoN enters the political within zones of indistinction. Moreover, any decisive criterion capable of distinguishing the SoN and the state of law, the norm and the exception, becomes subject to unconditional undecidability (Agamben will term this a perpetual crisis, a point we will return to). To quote Agamben at length:

self-consciously fictitious construct, deployed rhetorically to legitimise the existence of the state" (Foucault 2004: 270). According to Foucault, "sovereignty is found on a calculation that makes it possible to avoid war. It is founded on a nonwar" (ibid).

40. Figure taken from Agamben (1998: 38).

41. Figure taken from Agamben (1998: 38). 
The state of nature and the state of exception are nothing but two sides of a single topological process in which what was presupposed as external (the state of nature) now reappears, as a Möbius strip or a Leyden jar, in the inside (as state of exception), and the sovereign power is this very impossibility of distinguishing between outside and inside, nature and exception, physis and nomos. The state of exception is thus not so much a spatiotemporal suspension as a complex topological figure in which not only the exception and the rule but also the state of nature and law, outside and inside, pass through one another (Agamben 1998: 37).

The concentration of powers and violence within the sovereign becomes problematic specifically with respect to the potential merging of norm and exception (see fig. 3 ) that Agamben so clearly points to with respect to the current realpolitik situation. To quote Agamben (1998: 38): "What . . is still happening before our eyes is that the juridically empty' space of the state of exception . . . has transgressed its spatiotemporal boundaries and now, overflowing outside them, is starting to coincide with the normal order, in which everything again becomes possible." Agamben thus hints at the fact that it is especially in a post-contractual condition of established sovereignty that we encounter the potential for an actualization of precisely that violence, which arguably remains potential in the SoN (which Foucault [2004: 92] nicely illustrates as a "theater where presentations are exchanged"). Hobbes points to this radical, post-contractual potential explicitly: as he claims, dwelling in a unified manner in a sphere beyond the law, the Leviathan's "power ... ought to be greater, than of any, or all the subjects" (1985: 237-238).

Thus, the persistence of a state of war within society has two essential connotations, which Agamben thinks of as intertwined: first, the sovereign can only provisionally end the state of nature (that is, only as long as the multitude remains unified), and second, he is also necessarily exerting legal force over the multitude. The exception then has a twofold dimension for Agamben: on the one hand, the exception is the potential for war that is necessarily latent in the state (civil war waged by the multitude); on the other hand, it is the legal exception that legally grounds sovereignty, but only by way of integrating a space of anomie into the realm of the nomos. ${ }^{42}$

Within the SoL, the multitude's potential violence thus becomes combined with another form of violence that Agamben, on the grounds of a reading of Benjamin, Derrida, and Schmitt, terms force-of-law [the original text uses a Heideggerian kreuzweise Durchstreichung here, as should be noted], which implicitly points to the exception preceding the norm in legal terms. Here, Agamben relies on Schmitt's definition of the exception as the locus where the law is legally suspended to enforce it in arguing that there can be no all-encompassing grounding norm or arché [ả $\rho \chi \eta \dot{]}$ as a universally granting right that was universally consented to. Law in this sense is based on an absence of origin; it can-

42. Cf. Agamben's (1998: 18f.) reading of Schmitt: "The situation created in the exception has the peculiar characteristic that it cannot be defined either as a situation of fact or as a situation of right, but instead institutes a paradoxical threshold of indistinction between the two. It is not a fact, since it is only created through the suspension of the rule. But for the same reason, it is not even a juridical case in point, even if it opens the possibility of the force of law. This is the ultimate meaning of the paradox that Schmitt formulates when he writes that the sovereign decision 'proves itself not to need law to create law." 
not found itself but needs a Setzung (as is implied in the German Ge-Setz [law]), which implies a setzende subject or, in this case, the sovereign. Law in this sense is inextricably bound to dicere, to force, in the sense of violence [Gewalt]. For Agamben, the Hobbesian SoN is thus always-already and not so different from a state of exception in-following Benjamin's early insight ${ }^{43}$ - being the rule and incorporated within the norm. ${ }^{44}$ The state of nature as the alleged exception is thus far from being overcome in the SoL; rather, it is slightly transformed by being installed within a society, and created within and effectuated by a legal framework.

Related to this is an account of a form of actual violence that rests upon the convergence of law and violence in the figure of the sovereign, ${ }^{45}$ which becomes manifest in the context of generalized and instrumentally implemented states of exceptions. This violence is an institutionalised consequence of bare "force-of-law;" and is, thus, conditioned upon the contract's inability to incorporate the essential ungraspability of the law's origin. ${ }^{46}$ We will expand on this form of violence in the following passage.

For now, let me briefly summarize those far-reaching structural and strategic consequences arising with the merging of norm and exception as illustrated in Figure 3. Firstly, the sovereign is not merely beyond law, but also within it. Potentially, he is the law, for, as Norris (2005: 9) nicely reframes Agamben, "[by] identifying the threshold between legal and nonlegal, sovereignty defines them both." Secondly, the sovereign is total as he can possibly render law and life indistinct. Strikingly, within this shadowy zone, the reactualization of "becoming-wolf" is absolutely unexceptional, as "it is at every moment possible" (Agamben, 1998: 106).

\section{Reading the Contract as a Ban}

Keeping Agamben's concerns in mind, the "act of laying down" one's right at the very core of the Hobbesian contract can appear in a different light. On the grounds of a conflation of norm and exception, the act of contractual rights transfer can justifiably be read in a much more radical sense. If the norm conflates with the exception, the (arguably autonomous) decision preceding the contractual arrangement-the moment of "absolute presence" where the multitude becomes the sovereign, according to Agamben-is entirely suspended, as the SoN (where sovereignty could be redefined) is unattainable in its original form (that is, in the form of a disunited, not dissolved, multitude) without wag-

43. As Benjamin (quoted in Agamben, 1999: 160) puts it: "The tradition of the oppressed teaches us that the 'state of exception' in which we live is the rule."

44. See Benjamin (2010: 139). Cf. also Madung (2007: 37-41).

45. As Agamben (1998: 35) writes: "It is important to note that in Hobbes the state of nature survives in the person of the sovereign, who is the only one to preserve its natural ius contra omnes. Sovereignty thus presents itself as an incorporation of the state of nature in society, or, if one prefers, as a state of indistinction between nature and culture, between violence and law, and this very indistinction constitutes specifically sovereign violence. The state of nature is thus not truly external to nomos but rather contains its virtuality."

46. See Agamben's remarks in The State of Exception, especially chapters four and five, as well as Derrida's (1992a) influential reading of Benjamin's Critique of Violence. 
ing war against the sovereign to reenter the SoN. Now, if the exception is implemented within a juridical framework that is bound to the sovereign's decision alone and, further, where both norm and exception merge and eventually enter a terrain of undecideability, the multitude's passage from the state (norm) back toward the state of nature (the exception, and the disunited multitude) arguably becomes far more complicated, precisely as the state of nature is blurrily implied in the norm and is not merely external to it.

It is thus specifically at the very locus of the merging of norm and exception that we encounter the intrinsically aporetic structure at the origin of law that Walter Benjamin so thoroughly decoded in his "Critique of Violence," as Derrida's influential reading ("Force de Loi") has so articulately reminded us. ${ }^{47}$ "Applicability, 'enforceability', is not an exterior or secondary possibility that may or may not be added as a supplement to the law," Derrida thus claims in his famous lecture held at the Cardozo Law School in 1989, "it is the force essentially implied in the very concept of justice as law (droit), of justice as it becomes droit, of the law as 'droit' ..." (Derrida, 1989: 5). With this a priori conflation between violence and law (which becomes complicated in relation to a second conflation, that between norm and exception), the sovereign potentially becomes the incorporation of uncanniness; he can violently ignore the true "ultimate insolubility of all legal problems" ["die letztliche Unentscheidbarkeit aller Rechtsprobleme"] (Benjamin, 1996: 247) by himself, potentially emerging from it on the grounds of actualized decisions [Dezision] that are based on dicere (the term "dictator" in fact stems from dicere and dictare ${ }^{48}$ ) rather than respondere. To quote Derrida extensively from his second lecture in The Beast and the Sovereign I (2011: 57), "the most profound definition ... of the absolute of sovereignty, of that absoluteness that absolves it" is precisely that

[t] he sovereign does not respond, he is the one who does not have to, who always has the right not to, respond [répondre], in particular not to be responsible for [répondre de] his acts. He is above the law [le droit] and has the right [le droit] to suspend the law, he does not have to respond before a representative chamber or before judges, he grants pardon or not after the law has passed. The sovereign has the right not to respond, he has the right to the silence of that dissymmetry. He has the right to a certain irresponsibility... [emphasis mine]

In this respect, reminiscent of Schmitt's famous opening remarks in Political Theology, the sovereign is, in the first place, sovereign qua deciding rather than qua respond-

47. Derrida's "Force de loi" is in essence a critical reading of Benjamin's "Zur Kritik der Gewalt." Benjamin's text famously distinguished between law-preserving [rechtsetzende Gewalt] and lawmaking [rechtserhaltende Gewalt] violence, as well as between mythical and divine violence. Derrida's reading primarily centers around the ambivalence implied by the German term Gewalt, which can mean both a legitimate authority (and in this sense, power) as well as violence in the sense of force (cf. Derrida, 1989: 6). According to Derrida, law necessarily carries with it a notion of "force" (as is implied by the English "to enforce the law"). "Applicability, 'enforceability', is not an exterior or secondary possibility that may or may not be added as a supplement to the law. It is the force essentially implied in the very concept of justice as law (droit), of justice as it becomes droit, of the law as 'droit' ..." (Derrida, 1989: 5).

48. Cf. Carl Schmitt (2014: 232). See also his influential distinction between commissary and sovereign dictatorship (particulary chapters 1 and 4 in his Dictatorship). 
ing. To follow Agamben's argumentative course, sovereignty thus "presents itself as an incorporation of the SoN in society" (Agamben, 1998: 35) with bia [Bıa] (violence) and $d i k \bar{e}[\Delta i \kappa \eta]$ (justice) jointly entering a threshold; in this sense, the passage from the state of nature to the state of law is not least a movement "from one fear to another" (Derrida, 2009: 42). The Hobbesian "known disposition thereto," a potentiality of violence that can at any time be actualized on the grounds of a monopolized decision upon both exclusion and exception, is post-contractually still embodied in the "artificial," "Mortal God." This condition becomes all the more urgent with respect to the structural condition illustrated in Figure 3. Being the law, the sovereign inhabits the perpetual right to actually place individuals before it without having to restore a norm.

Nevertheless, to do justice to Hobbes, it is crucial to remark that while the sovereign's right is absolute, it faces a limitation if it intervenes with the right to self-preservation. ${ }^{49}$ According to Hobbes (1985: 272), the sovereign's accountability lasts only "as long as . . . the power lasteth by which he is able to protect them," insisting on the individual's right to self-preservation, which prevails within the state. ${ }^{50}$ While even Leviathan offers figures "that might without injustice be destroyed" (Ibid.: 232) (and who are thus reminiscent of Agamben's homines sacri in that they can be killed "without committing homicide" [1998: 83]), the Hobbesian outlaws have autonomously chosen to dwell outside of the city (in the sense that they were unwilling to sign the contract). To the contrary, bare life as defined by Agamben is actively produced and decided upon; it is inclusively excluded by the sovereign. Similar to Kafka's Before the Law (where the man from the country faces an infinite boundary banning him from entering the law), the law remains in force without significance, and is inaccessible to those before it. ${ }^{51}$ In Hobbes's scenario, individuals at the very least still obtain the possibility to "submit to ... decrees" (1985: 232).

However, to some extent, Hobbes fails to account for the fact that the act of "leaving one's right to the sovereign" bears the potential to not just in a Schmittian sense "demand ... from the members of its own nation the readiness to die," ${ }_{52}$ but also to strip the individual of any right, even of the right to have a right, to put it in Arendt's terms. Hobbes fails to account for those instances where self-preservation loses its meaning, as when the self becomes obsolete, or when it is violently laid bare, or when it cannot preserve itself as it is entirely powerless. Thus, although individuals constitute a sovereign"in order to live" (Foucault, 2004: 241), the ultimately violent paradox at the very core of sov-

49. With respect to this, see also Patton's (2007: esp. 214-217) paper on the link between Foucault and Agamben's stances on biopolitics.

50. As Hobbes (cf. 1985: 272) asserts, in the case that the sovereign acts against the individuals' right to self-preservation, individuals obtain the legitimation to re-enter the SoN via a civil war waged against the Sovereign.

51. As the man from the country in Kafka's Before the Law, Agamben's out-laws are unable to overcome the threshold that leads towards the Law's inside. Agamben's unorthodox interpretation of Kafka's parable is interesting in this regard (cf. Agamben, 1998: 49-62). The latter can be contrasted to Derrida's reading of the same parable (1992b).

52. Cf. Schmitt (2007: 46). It could be interesting to explore both Hobbes's and Schmitt's stances on the sovereign's relation to the individual right to self-preservation. Strauss (2007: 104-110) provides a thoughtful comparison here. 
ereignty cannot be fully resolved precisely since, to quote Foucault (2004: 240), "the lives and deaths of subjects become rights only as a result of the will of the sovereign."

The Hobbesian Mortall God thus, from the very origin of its institutionalization, bears the potential to-and here I use a Benjaminian (1998: 264) expression-become a "lord of creatures," applying an actualized undecidability onto the sphere of politics in refraining from defining distinctions necessary to protect bare life from the threat of indistinction arising from the contractually joint triangle of sovereignty-law-violence (cf. Agamben, 1998: 31). Crucially, in its becoming actual, post-contractual violence is exerted upon figures that are still somewhat within the sovereign's body, but as creatures, not as subjects-i.e., they are inclusively excluded. Thus, they find themselves exposed to a violence, which-here in suspending the potential not-to-be-becomes absolutely actual and truly unconditional.

\section{The Global Condition: (In)visible Potentials, Hidden Actualities}

Agamben's examination renders it obvious that in incorporating the SoN as the included exception, the actualization of the Hobbesian Common-Wealth rests on the nature of a form of violence, which, in modernity, goes far beyond that seemingly-envisioned by Hobbes (a means-end-rational-punishment for the sake of the preservation of the whole). ${ }^{53}$ For Agamben, contemporary violence is embedded in what might be termed "bio-thanatopolitics," i.e., an intermingling of Foucauldian bio-political power and sovereign totalitarian violence. In introducing value into politics, "bio-thanatopolitics" is accompanied by a form of violence that works on an entirely different level than in Hobbes (cf. Agamben 1998: 141). With the decision regarding the very definition of life itself having become juridical, violence here hides itself behind the veil of creationary positivity, which makes life defined by the sovereign.

For Agamben, the reality of contemporary sovereign politics is, thus, a politics of life and death itself, with the concepts of life and death having overcome their past mutual exclusion. Bare life reveals itself as the indeconstructible origin lying at the core of the social contract, being exposed to the sovereign sword of punishment. Even worse, following Agamben, the latter reveals itself as the Damocles sword hanging over anyone, ${ }^{54}$ as the reducibility to bare life is a universal condition; it is a form of potentiality which prevails, since its other-im-potentiality—has not succeeded in actualizing itself. As Agamben asserts (cf. 1998: 137), contemporary sovereign politics, then, creates creatural life, which, in being judged to be "unworthy of being lived," can be destroyed whatsoever. ${ }^{55}$ According to him, what we face today is the uncanniness of a politics that produces death for the sake of producing life (in the sense of "to make live and to make die" as a radicalisation

53. As Hobbes asserts, "A punishment, is an Evill inflicted by publique Authority, on him that hath done,

... to the end that the will of men may thereby the better be disposed to obedience" (1985: 353).

54. With respect to this, see also Agamben (1999c: 82-84).

55. Agamben refers to the first document that distinguished between valueless and valuable life in relation to euthanasia by Karl Binding and Alfred Hoche in 1920. 
of Foucault's biopolitical "to make live and to let die"); the hypothetically anticipated violence whose actualization Hobbes's "rational decider" opts against for the sake of selfpreservation has become the reality of a type of violence that does not dare to undermine the Hobbesian first law of nature alongside the right to self-preservation.

The type of violence Agamben has in mind finds its most violent illustration in the absolute evil of Nazi policies conducted on so-called VPs (Versuchspersonen) $)^{56}$ and, certainly, the Muselmann, described by Primo Levi (1959: 101-103) as "an anonymous mass, continuously renewed and always identical, of non-men who march[ed] and labor[ed] in silence, the divine spark dead within them, already too empty really to suffer ... the weak, the inept, those doomed to selection [for the gas chambers]." For Agamben, the Nazi concentration camps serve as bio-thanatopolitics' most extreme example. Respectively, he illustrates the figure of the Muselmann much in line with Adorno's early claim, taken from his "Meditations on Metaphysics," that "the individual no longer died in the concentration camp, but rather the exemplar," where the "individual is expropriated of the final and most impoverished which remained to it." ${ }^{77}$ Corpses here become a matter of serial production, with death becoming de-individualized and arbitrary. Eventually, the Nazis went as far as to integrate the encamped in the process of producing death (Didi-Huberman and Bauman have both elaborated on the so-called Sonderkommando in Auschwitz-Birkenau ${ }^{58}$, a group of selected encamped who were forced to work in the crematoria, they were liquidated and replaced after approximately four months of work).

For Agamben, after Auschwitz, little has changed since "non-men" were actively produced by the Nazis; little has been done to render impotential the condition(s) of possibility for the emergence of the Muselmann. It is well known that Agamben found their contemporary expression in figures such as the prisoners in Guantanamo Bay who were held in captivity under indefinite detention. However, it should be mentioned that his analogy has always been at risk of somewhat being a generalization. Surely, his comparison to the Third Reich is problematic, and I would agree here with Laclau that it potentially leads to a sort of "social indeterminacy." ${ }^{9}$ However, while Agamben's rhetoric might appear to be not very finely nuanced in this respect, he is surely right in insistently pointing to the alarming extension of precarious lives. As we might specify with Zygmunt

56. Agamben expands on Nazi Versuchspersonen, the overcomatose person and 'lebensunwertes Leben' in Chapters 3, 4, 5, and 6 of the third part of Homo Sacer.

57. Cf. Adorno, 1970: 355; my translation. Agamben expands on the figure of the Muselmann as the most extreme instance of homo sacer in Remnants of Auschwitz: The Witness and the Archive (cf. specifically Agamben, 2002: 41-86). I agree with LaCapra (2007) however, and find it important to question whether the figure of homo sacer suffices to account for the (arguably) far more complex nature of the Muselmann.

58. Cf. Bauman's (2001) analysis; as well as Didi-Huberman (2008).

59. Here, Agamben's claim seems to be a generalizing one. I suggest taking into more critical consideration whether certain phenomena, such as Guantamo Bay, the Nazi camps, refugee camps, etc., can legitimately be subsumed under the same category. A. Vasilache recently provided an insightful critique (Vasilache, 2007: 65-66). In a similar fashion, Laclau accuses Agamben of "essentialist unification" and "political nihilism." Although I think that Laclau's critique is not entirely justified, he provides few interesting points that seem useful for a potential critique. He also detects several argumentative and structural weaknesses that underpin Agamben's arguments (Laclau, 2007: 11-22). 
Bauman (Bauman, 2013: 65f.), it is the refugees, those "ban-optically" 60 surveilled, those who are encamped and forcefully determined by an "absence of a where to-the declared prohibition or practical impossibility of arriving anywhere else" who are doomed to be singled out. Even if biopolitical selection mechanisms have become subtler they are perhaps no less violent. Agamben is also right to insist that for precarious lives to come-into(abandoned) existence, the establishment of zones of indistinction remains a necessary, if not a sufficient, precondition, and that this topology has turned into contemporary global politics' "central paradigm" (Agamben, 2014). For him, the political logic that produced 12 years of Ausnahmezustand in the Third Reich prevails in a created threshold between life and law, and it does so in a radicalized sense: the implementation of institutionalized exceptions has become the political's very own condition of possibility ${ }^{61}$ in the form of a "perpetual coup detat" (Agamben, 2014).

In this sense, Agamben's account illustrates how violence itself has become structural in a radically different sense than Hobbes had envisioned or could have envisioned: it operates through structures on the grounds of geopolitical situations requiring response mechanisms far more complex than simple PDs. Violence is not visibly exerted by A over $\mathrm{B}$; rather, it works via mechanisms of exclusion/inclusion, or of producing life/letting (or even making) die. What is more, it reproduces itself on normative grounds and through biopolitical dispositifs, when to govern is to manage effectively, and to manage effectively is to carefully separate the productive from the unproductive, the People (capital P) from "people" (Agamben, 1993). Compare this focus on productivity to (a Straussian reading of) Hobbes: the entirety of the Leviathan is focused on the question of how to avoid a violent death. ${ }^{62}$ There is little, if no mention of the effectivity of life or of the perfecting of the body politik, even if this logic might find a first visual expression in the frontispiece of the Leviathan which seemingly unifies all individuals in one body. Biopolitics might thus be tacitly implied, yet if it is, then it is implied negatively (avoiding a violent death is arguably different than a focus on the productivity of life). In other words, from there, it is still a long road to travel to a utilitarian, Benthamite vision of the state as government occurring more than a century later. In Hobbes's vision, life was not (yet) to be made productive at the expense of some other; the question at stake was to avoid a worst-case scenario, i.e., to grant a considerable level of security to anybody willing to consent to the contract. In other words, at the core of the Hobbesian contract still lay a Decision (capital D) grounded on consent (and Hobbes was at least partly still concerned with respon-

6o. Didier Bigo's (2008: 8) concept of the "ban-opticon" can best be described as a conflation of Agamben's and Nancy's concepts of the ban (as forms of being inclusively excluded) and Foucauldian panoptical surveillance structures. Bigo accounts for the rise of a "Ban-opticon dispositif" to examine a new form of "governmentality of unease" that, according to him, characterises the post-9/11-era: "This form of governmentality of unease, or Ban, is characterized by three criteria: practices of exceptionalism, acts of profiling and containing foreigners, and a normative imperative of mobility."

61. Agamben provides a detailed account of the history of article 48 (he clearly draws on Schmitt's discussion of it at the end of Dictatorship), which he thinks is vital to take into account to truly understand Hitler's rise to power. See Agamben (2005: 12-16).

62. Strauss (1961) reads Hobbes in this sense, and I am convinced that he rightly focuses on the avoidance of death. Strauss here somewhat counters Esposito’s (2014) recent (biopolitical) reading of Hobbes. 
dere and not solely with dicere, even though, as Agamben has shown, a radical authoritarian potential is, by necessity, always-already latent in his conception of sovereignty). However, as Agamben (2014) clearly asserts, it is precisely this situation that has changed entirely: "The crisis, the judgement, is split from its temporal index and coincides now with the chronological course of time, so that-not only in economics and politics-but in every aspect of social life, the crisis coincides with normality and becomes, in this way, just a tool of government. Consequently, the capability to decide once for all disappears and the continuous decision-making process decides nothing."

In other words, the perpetual crisis undermines our own capacity to decide, as there is no clear situation wherein a decision could be made when faced with the merging between norm and exception. Alternatively, as Agamben (2015a) pointed out recently in an interview, there is a different, important connotation of "crisis" in ancient medicine, which meant a decisive moment when the doctor was confronted with the life or death of his patient. In this context, "crisis" meant judgement, and thus has an ancient connotation directly opposed to the current praxis of enduring indecision and postponement, a divergence that is not just of terminological importance.

I will expand on a few further and more general implications related to this discussion of "crisis" in the following, concluding remarks.

\section{Conclusion: Potential Is to Be, or, Crucially, Not to Be}

To conclude, I once again pick up on Virno's question raised at the very beginning of this paper, namely: "What is ... the effective relationship between the state of nature and the civil state?" What Agamben's reading of Hobbes has shown in response to this question, is, first, that the sovereign "decision" is always-already before any universal law, that there can be no all-encompassing arché of the nomos. It exceeds it by necessity, giving rise to an infinitely deferred actualization of the contract's hypothetical gift. In pointing to the ultimate aporia that underpins the law's paradoxical structure to which no abstraction can fully respond, Agamben not least confronts empty formalisms with their limits. ${ }^{63}$ As I would argue, this holds equally for veils of ignorance, basic norms, impartial observers, or, last but not least, "Mortall Gods" who fail at rendering the law's inherent violence as inexistent-be it actual or potential-for violence is always-already implied in the Setzung of the law, of Ge-Setz.

Furthermore, Agamben has explicitly revealed how the state of war is potentially implied in social settings in at least two ways: firstly, via the law's inability to fully incorporate the exception into the norm, and secondly, via the ultimate divergence between the multitude and the people in post-contractual settings. Following Agamben's arguments, these forms of inclusionary exclusion become complicated specifically, in a time when any proper "decision" (in the sense of judgement as etymologically implied in "crisis") is seemingly suspended by a peculiar conflation between norm and exception.

63. This, I would say, applies equally to Neo-Kantians as diverse as Kelsen and Rawls, both of whom partially rely on the law's empty formula, i.e., its pure form. 
Subsequently, the legitimate nature of Hobbes's argument needs to be questioned in a few further respects, specifically if read from a contemporary stance. First, it has to be critically remarked that the Hobbesian SoN, rather than being merely hypothetical, has always-already been more of a concrete abstraction of civil society (as MacPherson has rightly argued). It needs to be taken into account that Hobbes's SoN therefore still obtains a peculiar relation to allegedly "civilized states"; as Agamben asserts, there is a sense in which we have never managed to exit the state of nature. It is far from being a prejuridical condition; rather, it is the "exception and the threshold" dwelling within the state (Agamben, 1998: 106). Taking into account the contemporary condition, timely indications of tendencies towards states of war are manifold, and, as one might add, as it has always-already been inscribed into a "civilized" topography, it has always retained its elements of barbarism. ${ }^{64}$ Undoubtedly, its most significant examples are still to be found in those zones of indistinctions so rigorously depicted by Agamben. ${ }^{65}$ Thus, I suggest to rather view the SoN as always implied in the State, or as really just another side of a large coin (Virno). The question to be asked would then be, of course, what side of the coin, or which pole our social (dis)order(s) tend(s) to in the present, and in what ways states of war are implied and actualised within our societies.

Secondly, I suggest that Hobbes, and in specific, his account of the state of nature-if read, with Agamben, not merely as being opposed to the civil state, but rather, as alwaysalready inscribed into it as its very own exception-is of striking importance in another respect that I could only hint at in this study. What I described as a very early, implicit account of future-colonization could in some sense be translated into the contemporary, neoliberal condition with respect to the insights of authors such as Vogl, Streeck, or Berardi, all of whom hint at the fact that the future(s) is(are) currently being increasingly determined and colonized by financial transactions, which themselves construct futures via performative, self-fulfilling prophecies. In this sense, it could be argued that the predominance of financial capitalism shares certain facets with Hobbes's account of the state of nature, specifically regarding its time structure. As I tried to suggest briefly, Hobbes's account of the SoN essentially circles around the problem of the future, and specifically, insecurity, alongside the means adopted to solve it. Moreover, we should remember that Hobbes's state of nature was essentially grounded on potential, that is, for Hobbes, for there to be a state of war, a sufficient factor was a high likeliness for warlike states to unfold. Moreover, as I suggested, the nature of preventive, anticipatory reason as depicted by Hobbes was a significant factor for the emergence of a state of war.

To lend credence to the claim that Hobbes's account of the development of "anticipatory reason" shares certain features with the contemporary (allegedly post-contractual) condition, it is helpful to briefly point out that the French editorial collective Tiqqun (2011; cf. also Lyotard, 2004) has recently re-elaborated on the contemporary alliance between neoliberalism and cybernetics as a "Universal Automaton," thought of nowadays

64. This insight is, of course, not at all far from Adorno's and Horkheimer's early diagnosis in The Dialectic of Enlightenment.

65. Cf. also Prozorov in this regard (2009: 334). 
as a Leviathan without a specified sovereign, thereby essentially functioning as a perfect machine on the grounds of algorithmic determination and neoliberal governance (this, surely, is neoliberalism's peculiar way of trying to solve the problem of future contingency). Moreover, Serge Moscovici (1976) has elaborated on the development from what he calls a "mechanical" state of nature to a "cybernetic" one, regarding the nature of technology shaping individual action.

Above all, Franco "Bifo" Berardi (2012) has argued that what is lost in neoliberalism is an open future yet to come, a form of the future which can neither be predicted nor possessed. In a sense, Berardi adds to Agamben's account of a perpetual crisis which implies a radical lack of judgement in clearly articulating that the current crises we face are not simply the effects of the 2008 financial crisis alongside the separation of labor and capital, and the rise of what he (2012) calls "financial dictatorship." They are also, and probably most importantly, essentially caused by "a crisis of imagination about the future" (Ibid.: 8), closely connected to what Berardi terms an "ethical disorder" (Ibid.: 125); thus, we might add with a certain hint to Hobbes's elaboration on the state of nature, they might also be intensified by a certain form of "anticipatory reason." Such a crisis is embedded in global technology and linguistic machines producing idioms that reproduce an ideology of instrumental exchange rather than forms of gift-giving that would enable an ethico-social imaginary and a politics of attachment going beyond mere everydayeconomic transactions and instrumentalised feedback-mechanisms pervading the social. In a sense, Berardi's (Ibid.: 60-61) description of the current form of the public space is distinctly Hobbesian, depicting it as "a jungle wherein everyone is fighting against one another." Furthermore, we might add, recent sociological analyses of the level of interrelational competitiveness in contemporary neoliberal societies (such as those provided by German sociologists Hartmut Rosa [2006] and, most recently, Dietmar Wetzel [2013]) can lend high empirical credence to Berardi's implicit parallelization.

Thirdly, on the ground of the observation that Hobbes describes an abstraction of civil society, the content of an accurate "state of nature" in the sense of a state that is truly before the contract on behalf of Hobbes's description necessarily remains entirely fictional and speculative (that is, if deduced from an observation of civil society). In a way, then, Hobbes's account of a state of nature before an already established civil state is surely a myth, or in a Rousseauean sense, a fiction in a similar manner as the volonté générale is, and as sovereignty itself is. In Hobbes's own terms, sovereignty is based on artificiality (Agamben indeed speaks of an "optical illusion" [2013: 28] in this context). To quote Agamben (2015: 41) once more: "In other words, the state of nature, is a mythological projection into the past of civil war; conversely, civil war is a projection of the state of nature into the city: it is what appears when one considers the city from the perspective of the state of nature."

While any coherent picture of an actual state of nature before the contract arguably remains beyond Hobbes's grasp, this study argued that it is nevertheless vital to rethink the logics underpinning the Hobbesian SoN (specifically, if it is understood as an abstraction of civil society). In fact, doing so might serve as a powerful tool for a contemporary cri- 
tique of sovereignty, especially regarding Agamben's (Aristotelian) distinction between potentiality and actuality. As Agamben (1998: 44) notes, "Until a new and coherent ontology of potentiality ... has replaced the ontology founded on the primacy of actuality and its relation to potentiality, a political theory freed from the aporias of sovereignty remains unthinkable." If, grounded on Agamben's (Aristotelian) assertion that a potential is both the potential to-be and the potential not-to-be, what has to be considered are precisely the prospects for an actualization of the potential not-to-be that entirely excludes any remaining potential-to-be. Alongside Foucault, we should take into account those prospects; they are to be found in the fact that the SoN is a "condition of Warre," and not yet a Warre.

Even on game-theoretical terrain, reconstructions of Hobbes's state of nature have pointed out that there might be greater prospects for cooperative behavior amongst agents in anarchy than Hobbes's imagination was willing to admit. ${ }^{66}$ It is these actual prospects that need to be taken into further consideration. The sources of mistrust evolving in the Hobbesian "condition to Warre" need to be explored. If A believes B to be shortsighted, A will not cooperate, no matter what kind of person B actually is. Why would he believe that A would not cooperate? Additionally, how would an actualization of the potential not-tobe have to materialize? What would a concrete action actualizing a potential-not-to-be demand from us? A becoming-aware of the sources of mistrust might, as I deliberately suggest here, serve as a major contribution towards a truly post-sovereign politics in Agamben's sense. This would be a politics which, from an "interstitial distance," ${ }^{67}$ confronts the fact that bare life is produced, the fact that for bare life to come into being, a threshold between law and life needed to be created. Such a politics would respond that Hobbes's SoN is a "condition to Warre," and that Agamben's zones of indistinction are unconditional while realizing that conditional is not yet un-conditional. Finally, this would be a politics that explores the potentialities silently opened up by Hobbes himself in not yet speaking of "Warre." It would go "beyond the state in the state." 68

As Levinas (1999: 159-160) critically remarks, it is "not without importance to know if the egalitarian and just State in which man is fulfilled [...] proceeds from a war of all against all, or from the irreducible responsibility of the one for all.” In other words, the question to be raised is not least an ethical one; what comes before sovereignty? What is there and could there be anything before a thinking that is future-driven, or before a

66. Specifically, Kavka (1983) rigorously attacks Hobbes's assumption that anticipatory attack is the most reasonable policy. In this respect, I consider Hampton's $(1985 ; 1986 ; 1991)$ claims fruitful as well, alongside Axelrod's (1987) studies on cooperative behavior and iterated PDs.

67. I follow the idea behind Simon Critchley's notion of 'interstitial distance' here. As Critchley asserts, the political act of resistance happens "in a situation that articulates an interstitial distance from the state and allows for the emergence of new political subjects who exert a universal claim.” Moreover, he asserts that "working at an interstitial distance from the state" might help to "construct political subjectivities that are not arbitrary or relativistic, but which are articulations of an ethical demand whose scope is universal and whose evidence is faced in a concrete situation" (Critchley, 2004: 92). I explicate such a politics alongside the relation between Hobbes and Levinas in more detail in "Fighting for the Other's Rights First: Levinasian Perspectives on Occupy Gezi's Standing Protest," which is forthcoming in Culture, Theory and Critique.

68. I draw on Levinas' (1996) essay "Beyond the State in the State” here. 
thinking that restlessly aims at self-preservation? Can there be such a before, and would that "before" be a rendering im-potential of potentiality, a rendering im-potential of a "condition of Warre," as it were? Speaking with Derrida and Bennington (1999: 188), we must "try to think the gift before exchange, and the law before the contract." In this sense, it is about time to explore Hobbes's uncanny contemporariness to think through its ethical consequences, and not in the least instance, to think with Hobbes against Hobbes.

\section{References}

Adorno T. W., Horkheimer M. (1969) Dialektik der Aufklärung, Frankfurt am Main: S. Fischer.

Adorno T. W. (1970) Negative Dialektik, Frankfurt am Main: Suhrkamp.

Agamben G. (1993) Tiananmen. The Coming Community, Minneapolis: University of Minnesota Press, pp. 85-89.

Agamben G. (1998) Homo Sacer: Sovereign Power and Bare Life, Stanford: Stanford University Press.

Agamben G. (1999a) The Man Without Content, Stanford: Stanford University Press.

Agamben G. (1999b) Potentialities: Collected Essays in Philosophy, Stanford: Stanford University Press.

Agamben G. (1999c) Remnants of Auschwitz: The Witness and the Archive, New York: Zone Books.

Agamben G. (2005) State of Exception, Chicago: University of Chicago Press.

Agamben G. (2013) Leviathans Rätsel / Leviathan's Riddle, Tübingen: Mohr-Siebeck.

Agamben, G. (2014) From the State of Control to a Praxis of Destituent Power. ROAR Magazine, February 14, 2014. Available online: http://roarmag.org/2014/o2/agambendestituent-power-democracy/ (accessed 15 September 2014).

Agamben G. (2015a) The Endless Crisis as an Instrument of Power: In Conversation with Giorgio Agamben. Available online: http://www.versobooks.com/blogs/1318-theendless-crisis-as-an-instrument-of-power-in-conversation-with-giorgio-agamben (accessed 27 July 2015).

Agamben G. (2015b) Stasis: Civil War as a Political Paradigm, Edinburgh: Ediburgh University Press.

Aristotle (2002) Metaphysics, Santa Fe: Green Lion Press.

Axelrod R. (1987) The Evolution of Cooperation, New York: Basic Books.

Axelrod R., Keohane R. O. (1985) Achieving Cooperation under Anarchy-Strategies and Institutions. World Politics, vol. 38, no 1, pp. 226-254.

Barbour C., Pavlich G. (2009) After Sovereignty: On the Question of Political Beginnings, London: Routledge.

Barry B. (2010) Political Argument, London: Routledge.

Bauman Z. (2001) Modernity and the Holocaust, New York: Cornell University Press.

Bauman Z., Lyon D. (2013) Liquid Surveillance, Cambridge: Polity.

Berardi F. (2012) The Uprising: On Poetry and Finance, Los Angeles: Semiotext(e). 
Benjamin W. (1996) Critique of Violence. Selected Writings, Vol. I: 1913-1926 (eds. M. Bullock, M. W. Jennings), Cambridge and London: Harvard University Press, pp. 236-252. Benjamin W. (1999) Zur Kritik der Gewalt. Gesammelte Schriften, Vol. 2, 1, Frankfurt am Main: Suhrkamp, pp. 179-204.

Benjamin W. (1998) The Origin of German Tragic Drama, London: Verso.

Benjamin W. (2010) Über den Begriff der Geschichte, Frankfurt am Main: Suhrkamp.

Bennington G., Derrida J. (1999) The Gift, Jacques Derrida, Chicago: University of Chicago Press.

Bigo D. (2008) Globalized (In)Security: The Field and the Ban-Opticon. Terror, Insecurity and Liberty: Illiberal Practices of Liberal Regimes After 9/11 (eds. D. Bigo, A. Tsoukala), Abingdon: Routledge, pp. 10-48.

Braybrookes D. (1985) The Insoluble Problem of the Social Contract. Paradoxes of Rationality and Cooperation (eds. R. Campbell, L. Sowden), Vancouver: University of British Columbia Press, pp. 277-305.

Clastres P. (2010) Archeology of Violence, Los Angeles: Semiotext(e).

Critchley S. (2004) Infinitely Demanding: Ethics of Commitment, Politics of Resistance, London: Verso.

Critchley S (2014) What is the Institutional Form of Thinking? Derrida and the Future of Liberal Arts: Professions of Faith (eds. M. Caputi, V. K. Del Casino, Jr.), London: Bloomsbury, pp. 37-46.

Deleuze G. (1962) Cours de M. Deleuze-Sorbonne 1959-1960: Unpublished Lecture Notes. Available online: http://www.webdeleuze.com/php/texte.php? cle=232\&group $\mathrm{e}=$ Rousseau\&langue $=1$ (accessed 15 September, 2014).

Derrida J. (1978) Cogito and the History of Madness, Writing and Difference, London: Routledge.

Derrida J. (1992a) Force of Law: The "Mystical Foundation of Authority." Deconstruction and the Possibility of Justice (eds. D. Cornell, M. Rosenfeld, D. G. Carlson), London: Routledge, pp. 3-67.

Derrida J. (1992b) Before the Law. Acts of Literature (ed. D. Attridge), London: Routledge, pp. 181-220.

Derrida J. (2011) The Beast and the Sovereign, Vol. 1, Chicago: University of Chicago Press.

Didi-Huberman (2008) Images Inspite of All: Four Photographs from Auschwitz, Chicago: University of Chicago Press.

Donnelly J. (2000) Realism and International Relations, Cambridge: Cambridge University Press.

Edkins J. (2007) Whatever Politics. Giorgio Agamben: Sovereignty and Life (eds. M. Calarco, S. DeCaroli), Stanford: Stanford University Press, pp. 70-91.

Esposito R. (2014) Das Paradigma der Immunisierung. Biopolitik: Ein Reader (eds. T. Lemke, A. Volkers), Berlin: Suhrkamp, pp. 337-382.

Filippov A. F. (2013) The Other "Hobbes People": An Alternative Reading of Hobbes. Journal of Classical Sociology, vol. 13, no 1, pp. 113-135. 
Fitzpatrick P. (2005) Bare Sovereignty: Homo Sacer and the Insistence of Law. Politics, Metaphysics and Death: Essays on Giorgio Agamben's Homo Sacer (ed. A. Norris), Durham: Duke University Press, pp. 49-73.

Foucault M. (2004) Society Must be Defended: Lectures at the College de France, 1975-1976, London: Penguin Books.

Gauthier D. (1969) The Logic of Leviathan: The Moral and Political Theory of Thomas Hobbes, Oxford: Oxford University Press.

Gilbert J. (2014) Common Ground: Democracy and Collectivity in an Age of Individualism, London: Pluto Press.

Grayling A. C. (2010) Liberty in the Age of Terror: A Defence of Civil Liberties and Enlightenment Values, London: Bloomsbury.

Hacking I. (1975) The Emergence of Probability: A Philosophical Study of Early Ideas about Probability, Induction and Statistical Inference, Cambridge: Cambridge University Press.

Haji I. (1991) Hampton on Hobbes on State of Nature Cooperation. Philosophy and Phenomenological Research, vol. 51, no 3, pp. 589-601.

Hampton J. (1985) Hobbes's State of War. Topoi, vol. 4, pp. 47-6o.

Hampton J. (1986) Hobbes and the Social Contract Tradition, Cambridge: Cambridge University Press.

Hampton J. (1991) Cooperating and Contracting: A Reply to I. Hajis "Hampton on Hobbes's State of Nature Cooperation." Philosophy and Phenomenological Research, vol. 51, no 3, pp. 603-609.

Heller-Roazen D. (1999) Editor's Introduction: “To Read What Was Never Written.” Potentialities: Collected Essays in Philosophy (ed. D. Heller-Roazen), Stanford: Stanford University Press, pp. 1-23.

Hobbes T. (1983) De Cive: The Latin Version, Oxford: Clarendon Press.

Hobbes T. (1985) Leviathan, Westminster: Penguin Books.

Kavka G. (1983) Hobbes's War of All against All. Ethics, vol 93, pp. 291-310.

LaCapra D. (2007) Approaching Limit Events: Siting Agamben. Giorgio Agamben: Sovereignty and Life (eds. M. Calarco, S. DeCaroli), Stanford: Stanford University Press, pp. $126-162$.

Laclau E. (2007) Bare Life or Social Indeterminacy? Giorgio Agamben: Sovereignty and Life (eds. M. Calarco, S. DeCaroli), Stanford: Stanford University Press, pp. 11-22.

Levi P. (1959) If This Is a Man, New York: The Orion Press.

Levinas E. (1996) Beyond the State in the State. New Talmudic Readings, Pittsburgh: Duquesne University Press, pp. 79-107.

Levinas E. (1999) Otherwise than Being or Beyond Essence, Pittsburgh: Duquesne University Press.

Lyotard J.-F. (2004) Libidinal Economy, London: Continuum.

MacPherson C. B. (1962) The Political Theory of Possessive Individualism: Hobbes to Locke, Oxford: Clarendon Press. 
Madung O. G. Nd. (2007) Politik und Gewalt: Giorgio Agamben und Jürgen Habermas im Vergleich, München: Herbert Utz.

Michaelis L. (2007) Hobbes's Modern Prometheus: A Political Philosophy for an Uncertain Future. Canadian Journal of Political Science, vol. 9, no 1, pp. 101-127.

Mills C. (2007) Biopolitics: Liberal Eugenics and Nihilism. Giorgio Agamben: Sovereignty and Life (eds. M. Calarco, S. DeCaroli), Stanford: Stanford University Press, pp. 185202.

Moscovici S. (1976) Society against Nature: The Emergence of Human Societies, London: Harvester Wheatsheaf.

Nancy J.-L. (1993) The Birth to Presence, Stanford: Stanford University Press.

Nancy J.-L. (2003) A Finite Thinking, Stanford: Stanford University Press.

Norris A. (2005) Introduction: Giorgio Agamben and the Politics of the Living Dead. Politics, Metaphysics and Death: Essays on Giorgio Agamben's Homo Sacer (ed. A. Norris), Durham: Duke University Press, pp. 1-30.

Oakeshott M. (1975) Hobbes on Civil Association, Oxford: Basil Blackwell.

Parsons T. (1937) The Structure of Social Action, New York: McGraw-Hill.

Patton P. (2007). Agamben and Foucault on Biopower and Biopolitics. Giorgio Agamben: Sovereignty and Life (eds. M. Calarco, S. DeCaroli), Stanford: Stanford University Press, pp. 203-218.

Plautus T. M. (2006) Asinaria (ed. John Henderson), Madison: University of Wisconsin Press.

Prozorov S. (2009) The Appropriation of Abandonment: Giorgio Agamben on the State of Nature and the Political. Continental Philosophy Review, vol. 42, no 3, pp. 327-353.

Rapaczynski A. (1989) Nature and Politics: Liberalism in the Philosophies of Hobbes, Locke and Rousseau, Ithaka: Cornell University Press.

Rasch W. (2007) From Sovereign Ban to Banning Sovereignty. Giorgio Agamben: Sovereignty and Life (eds. M. Calarco, S. DeCaroli), Stanford: Stanford University Press, pp. 92-108.

Rawls J. (2003) A Theory of Justice, Harvard: Harvard University Press.

Rawls J. (2007) Lectures on Political Philosophy, Cambridge: Harvard University Press.

Rosa H. (2006) Wettbewerb als Interaktionsmodus: Kutlurelle und sozialstrukturelle Konsequenzen der Konkurrenzgesellschaft. Leviathan, vol. 34, no 1, pp. 82-104.

Schmitt C. (2005) Political Theology: Four Chapters on the Concept of Sovereignty, Chicago: University of Chicago Press.

Schmitt, C. (1996a) Roman Catholicism and Political Form, Westport: Greenwood.

Schmitt, C. (1996b) The Leviathan in the State Theory of Thomas Hobbes: Meaning and Failure of a Symbol, Westport: Greenwood.

Schmitt C. (2007) The Concept of the Political, Chicago: University of Chicago Press.

Schmitt C. (2014) Dictatorship: From the Origin of the Modern Concept of Sovereignty to Proletarian Class Struggle, Cambridge: Polity Press.

Skinner Q. (1998) Liberty before Liberalism, Cambridge: Cambridge University Press. 
Strauss L. (2007) Notes on the Concept of the Political. Schmitt C., The Concept of the Political, Chicago: University of Chicago Press, pp. 99-122.

Strauss L. (1961) The Political Philosophy of Thomas Hobbes: Its Basis and its Genesis, Chicago: University of Chicago Press.

Streeck W. (2014) Buying Time: The Delayed Crisis of Capitalism, London: Verso.

Tiqqun (2001) The Cybernetic Hypothesis. Available at: http://theanarchistlibrary.org/ library/tiqqun-the-cybernetic-hypothesis (accessed 16 July, 2015).

Vasilache A. (2007) Gibt es überhaupt Homines sacri? Das nackte Leben zwischen Theorie und Empirie. Die gouvernementale Maschine: Zur politischen Philosophie Giorgio Agambens (eds. J. Böckelmann, F. Meier), Münster: Unrast, pp. 58-74.

Van Krieken R. (2002) The Paradox of the "Two Sociologies": Hobbes, Latour and the Constitution of Modern Social Theory. Journal of Sociology, vol. 38, no 3, pp. 255-273. Virno P. (2008) Multitude: Between Innovation and Negation, Los Angeles: Semiotext(e). Vogl J. (2014) The Specter of Capital, Stanford: Stanford University Press.

Vogl J. (2015) Der Souveränitätseffekt, Zürich: Diaphanes.

Wetzel D. (2013) Soziologie des Wettbewerbs, Wiesbaden: Springer.

\title{
Нормализованные исключения и тотализованные потенциальности: насилие, суверенитет и война в философии Томаса Гоббса и Джорджо Агамбена
}

\author{
Анна-Верена Ностхоффр \\ Франкфуртский университет имени Иоганна Вольфганга Гёте \\ Адрес: Theodor-W.-Adorno-Platz 1, 60323 Frankfurt am Main, Germany \\ E-mail: anna.verena.nosthoff@googlemail.com
}

В статье критически рассматривается связь между суверенитетом, насилием и войной в «Homo Sacer» Джорджо Агамбена и «Левиафане» Томаса Гоббса. Вкратце остановившись на новом прочтении основных положений «Левиафана», явным образом отсылающих к аристотелевскому различению актуального и потенциального, я прихожу к выводу, что насилие до общественного договора, по Гоббсу, прежде всего основано на том, что он называл «антиципирующим разумом», и проблеме контингентности будущего. В соответствии с интуициями М.Фуко, я также утверждаю, что допущение определенных потенциальностей ведет к известным выводам Гоббса о естественном состоянии как состоянии войны («condition of Warre»). На втором этапе я анализирую некоторые утверждения Агамбена с целью описать, как воображенное Гоббсом насилие до общественного договора не может быть преодолено в результате появления суверена. В частности, доводы Агамбена проливают свет на неразличимую и неразрывную взаимосвязь естественного состояния и состояния закона, которые, как пишет П. Вирно, являются «сиамскими близнецами». Таким образом на мета-уровне Агамбен предполагает, что Гоббсова проблема не сводима к «проблеме порядка» (по Парсонсу). Предпринятый анализ проблематизации будущего в работах Гоббса позволяет понять, как работают современные стратагемы на финансовых рынках и механизмы освоения будущего (future-colonization), лежащие в основе глобальной политики. В ответ на критику Агамбена я утверждаю, что тщательный анализ того, что можно 
обозначить как «перспективы актуализации потенциального не-бытия», может быть первым теоретическим шагом на пути к эффективной форме критики.

Ключевые слова: Джорджо Агамбен, Мишель Фуко, Томас Гоббс, насилие, состояние войны, чрезвычайное положение, танатополитика, неолиберализм 